\author{
$\mathrm{ERNiFeCr}-2$ 용가재 적용에 따른 CM247LC 초내열합금 \\ 용접부 응고균열 민감도 변화 거동 \\ 김경민 ${ }^{1 \dagger} \cdot$ 정혜은 ${ }^{\dagger} \cdot$. 정예선 ${ }^{1} \cdot$ 이의종 ${ }^{3} \cdot$ 이형수 $^{4} \cdot$ 서성문 $^{4} \cdot$ 천은준 $^{1,2, *}$ \\ 1경남대학교 메카트로닉스공학과 \\ 2경남대학교 신소재공학과 \\ 3두산중공업 GT소재기술팀 \\ 4한국재료연구원 고온재료연구실
}

\title{
Effect of ERNiFeCr-2 Filler Metal on Solidification Cracking Susceptibility of CM247LC Superalloy Welds
}

\author{
Kyeong-Min Kim ${ }^{1, \dagger}$, Hye-Eun Jeong ${ }^{2, \dagger}$, Ye-Seon Jeong ${ }^{1}$, Uijong Lee ${ }^{3}$, Hyungsoo Lee ${ }^{4}$, \\ Seong-Moon $\mathrm{Seo}^{4}$, and Eun-Joon Chun ${ }^{1,2, *}$
}

\begin{abstract}
${ }^{1}$ Department of Mechatronics Engineering, Kyungnam University, Changwon 51767, Republic of Korea ${ }^{2}$ Department of Advanced Materials Science and Engineering, Kyungnam University, Changwon 51767, Republic of Korea ${ }^{3}$ Gas Turbine Materials Engineering Team, Doosan Heavy Industries and Construction, Changwon 51711, Republic of Korea ${ }^{4}$ High Temperature Materials Group, Korea Institute of Materials Science, Changwon 51508, Republic of Korea
\end{abstract}

\begin{abstract}
The metallurgical aspects of weld solidification cracking in Ni-based superalloys (with $\mathrm{Ti}+\mathrm{Al}>5$ mass\%) have not been widely investigated thus far. Herein, the solidification cracking susceptibility of the CM247LC superalloy and its welds with ERNiFeCr-2 filler wire was quantitatively evaluated using a novel modified Varestraint testing method, for the successful manufacturing of CM247LC superalloy gas turbine blades. It was found that the solidification brittle temperature range (BTR) of the CM247LC superalloy was $400 \mathrm{~K}$. This measurement was obtained with a high-speed thermo-vision camera. The BTR increased to 486 $\mathrm{K}$ for the CM247LC/ERNiFeCr-2 welds (dilution ratio: 74\%). Theoretical calculations (i.e., the Scheil equation, performed using Thermo-Calc software) were conducted to determine the temperature range in which both solid and liquid phases coexist, together with the microstructural characterization of the solidification cracking surfaces. The greater increase in BTR for the CM247LC/ERNiFeCr-2 welds than that for CM247LC was attributed to the enlargement of the solid-liquid coexistence temperature range. This correlated with the formation of a low-temperature Laves phase during the terminal stage of solidification, and was affected by the diluted $\mathrm{Nb}$ and Fe components in the ERNiFeCr-2 filler metal. Based on the experimental and theoretical results, the proposed modified Varestraint testing method for dissimilar welds is expected to be an effective testing process for solidification cracking behavior in the manufacturing of high-soundness CM247LC superalloy welds.
\end{abstract}

(Received June 24 2021; Accepted July 16, 2021)

Keywords: gas turbine blade, CM247LC, ERNiFeCr-2, solidification cracking susceptibility, varestraint test

\section{1. 서 론}

- 김경민 · 정예선: 석사과정, 정혜은: 학사과정, 이의종 · 이형수 · 서성문: 연구원 , 천은준: 교수

*Corresponding Author: Eun-Joon Chun

[Tel: +82-55-249-2695, E-mail: ejchun@kyungnam.ac.kr]

Copyright (C) The Korean Institute of Metals and Materials

$\dagger$ Kyeong-Min Kim and Hye-Eun Jeong contributed equally to this work
CM247LC는 Mar-M247 합금의 일부 성분을 조절하여 주조 건전성 및 고온 기계적 성질을 개선시킨 $\mathrm{Ni}$ 계 초내 열합금이며, 약 $60 \%$ 의 $\gamma^{\prime}$ 석출상이 우수한 고온 기계적 성질을 발현한다 $[1,2]$. 최근 국내에서는 $\mathrm{CM} 247 \mathrm{LC}$ 초내 열합금의 가스터빈 블레이드 적용을 위한 핵심 소재가공 
기술개발이 진행되고 있다. 특히 블레이드는 제조 최종 단 계에서 용접 및 접합공정을 필요로 하기 때문에, $\mathrm{CM} 247 \mathrm{LC}$ 초내열합금 용접부 건전성은 블레이드의 기계 적, 화학적 성능과 직결된다고 할 수 있다. 하지만 $\mathrm{Al}+\mathrm{Ti}$ 함량 $5 \%$ 이상의 난용접(non-weldable) 소재로 알려진 $\mathrm{CM} 247 \mathrm{LC}$ 초내열합금은, 일부 선행 연구로부터 다양한 용 접 고온균열(응고, 액화, 연성저하 및 변형시효균열) 현상이 보고되고 있는 바, 각 균열 현상의 면밀한 제어 없이는 $\mathrm{CM} 247 \mathrm{LC}$ 합금의 블레이드 적용이 불가능하다 [3-5].

용접 응고균열(solidification crack)은, 고상액상 공존영역 (mushy zone)에서 형성되는 고온균열로, i)모재 및 용접소 재의 화학성분, ii)과냉, 응고편석 등 용접 공정변수에 따른 금속 응고거동, 그리고 iii)응고 수축과 용접 구속력 등의 열적-기계적 변형도의 복합 상호작용으로 인해 형성되는 것으로 알려져 있다 [6-8]. 응고균열 현상의 메커니즘 연구 는 1940년대부터 수행되어 왔으며, 큰 틀에서 'ShrinkageBrittleness Theory' [9]와 'Strain Theory'를 시작으로 [10], Borland 및 Matsuda에 의한 'Generalized Theory' [11] 및 'Modified Generalized Theory' [12] 로 발전되어 왔다. 특히 Matsuda는 응고 최종단계의 액막(liquid film) 형성거동에 고온 연성곡선과 응고취성 온도범위(solidification brittle temperature range, BTR)의 개념을 접목하였으며 [13], Prokhorov는 이러한 개념에 용접 시의 열적-기계적 변형도를 반영하여 응고균열의 발생 유무를 평가하는 통합 이론을 제시하였다('Technological Strength Theory') [14]. 이외에도 응고 시의 액상 공급량과 응고 수축량의 상관관계 에 기반한 ROF-ROS (Rate of Feeding-Rate of Shrinkage) 모델 [15] 등 다양한 이론들이 제안되었으나, 'Technological Strength Theory'를 기반으로 한 용접 응고균열 현상의 이해 및 제어가 가장 보편적으로 활용되고 있다. 그림 1 은 해당 이론의 개념을 응고시점의 고상, 액상 분포와 함께 모식적 으로 설명하고 있다. 'Technological Strength Theory'에 따르면 응고균열의 핵심 민감도 지표는 BTR과 균열 발생 에 요구되는 최소변형도 $\left(\varepsilon_{\mathrm{min}}\right)$, 임계변형률(critical strain rate, CSR)로 구분할 수 있으며, 각 민감도의 이해를 위해 덴드라이트 성장거동에 대한 'Kurz-Giovanola-Trivedi $(\mathrm{KGT})$ ' 및 응고편석 모델 기반의 BTR 해석 [16-18], 그 리고 잔류 액상의 국부압력에 대한 'Rappaz-DrezetGremaud (RDG)' 모델 기반의 CSR 해석 [19-21]들이 대 표적으로 적용되고 있다.

한편, 그림 1 에서 설명한 응고균열 민감도 지표를 평가 하기 위해 현재까지 약 150 여종의 다양한 시험법들이 활 용되어 왔다 [8]. 대표적인 시험법으로는 자기 구속형 시험

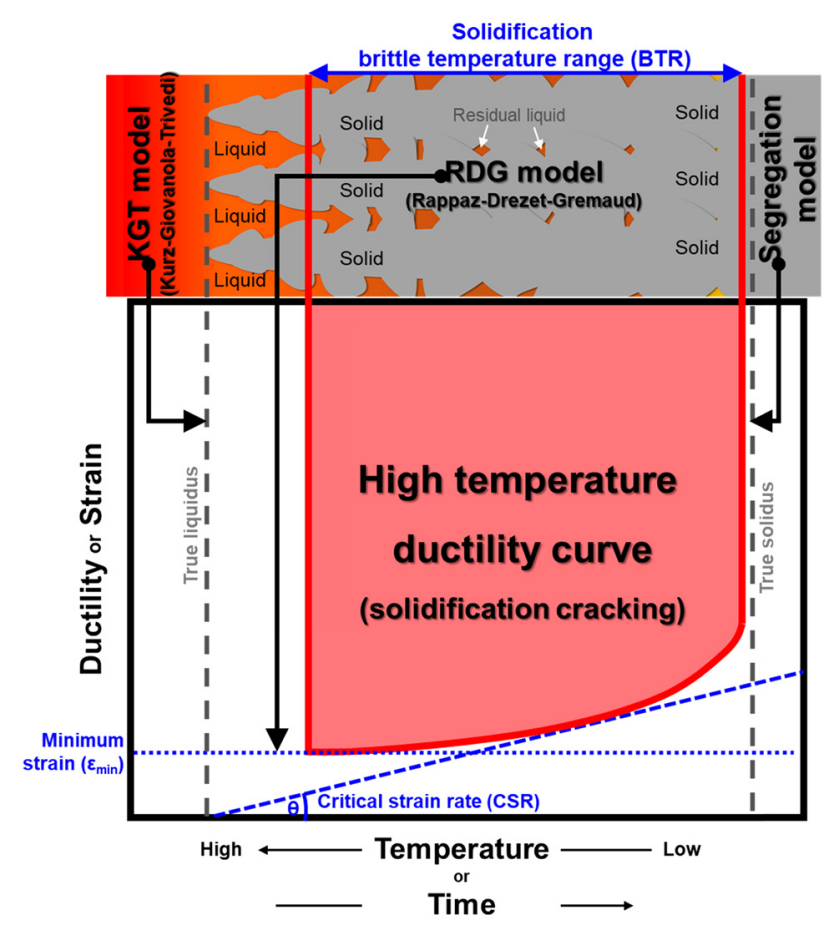

Fig. 1. Schematic description of high-temperature ductility curve for solidification cracking susceptibility and its representative theoretical modeling methods.

법(self-restraint test)에 속하는 Sigmajig Test [22], U-Type Hot Cracking Test [23], Cast Pin Tear Test [24,25], 외 부 하중 부가형 시험법(externally loaded test)에 속하는 Controlled Tensile Weldability(CTW) 시험 [26], Programmable Deformation Rate(PVR) 시험 [27], Varestraint Test [28] 등이 있다. 이 중에서 학술 연구에서 실 용접산업까지 가장 보편적으로 활용되고 있는 시험법은 Varestraint 시험이라고 할 수 있다. 해당 시험은 1965년 Savage에 의해 처음 제안되었으며, 용접부에 부가하는 변 형 값을 정량적으로 조절하여 $\varepsilon_{\min }$ 및 $\mathrm{CSR}$ 을 평가함과 동 시에, 용접 응고 열이력을 토대로 BTR 도출이 가능하다는 특징으로, 상기 ‘Technological Strength Theory'에 잘 접 목되어왔다. 세부 시험 방식의 다양화와 함께 용접부의 응 고균열(transverse-Varestraint), 액화 및 연성저하균열 (longitudinal, spot-Varestraint) 민감도 정량 평가에 활용되 고 있고, AWS B 4.0, ISO 17641-3에 의해 규격화 되는 등 평가 방식에 대한 표준화에 있어서도 타 시험법 대비 가장 완성도가 높다고 할 수 있다. 하지만 최근 용접산업 에서는 급속 승온과 냉각을 수반하는 고에너지 밀도 열원 적용 및 소재 다변화로 인한 이종 용접구조 증가, 적층제 조 보급확대 등 다방면의 기술 고도화가 이루어지고 있는 
Table 1. Chemical composition of materials used (mass\%).

\begin{tabular}{ccccccccccccccccccc}
\hline Materials & $\mathrm{Ni}$ & $\mathrm{C}$ & $\mathrm{Cr}$ & $\mathrm{Fe}$ & $\mathrm{Co}$ & $\mathrm{Mo}$ & $\mathrm{Mn}$ & $\mathrm{W}$ & $\mathrm{Ta}$ & $\mathrm{Nb}$ & $\mathrm{Ti}$ & $\mathrm{Al}$ & $\mathrm{B}$ & $\mathrm{Zr}$ & $\mathrm{Hf}$ & $\mathrm{Si}$ & $\mathrm{P}$ & $\mathrm{S}$ \\
\hline $\begin{array}{c}\text { CM247LC } \\
\text { (Base metal) }\end{array}$ & Bal. & 0.07 & 8.1 & - & 9.2 & 0.5 & - & 9.5 & 3.2 & - & 0.7 & 5.6 & 0.015 & 0.015 & 1.4 & - & $<0.0006$ & $<0.0002$ \\
$\begin{array}{c}\text { ERNiFeCr-2 } \\
\text { (Filler) }\end{array}$ & Bal. & 0.05 & 17.5 & 20.1 & 0.03 & 3.0 & 0.06 & - & 0.28 & 4.84 & 0.9 & 0.5 & - & - & - & 0.09 & $<0.005$ & $<0.001$ \\
\hline
\end{tabular}

시점이며, 결과적으로 오랜 기간 일률적으로 사용된 Varestraint 시험과정 및 고온균열 민감도 도출 방식에 대한 한계점 검토, 요소 기술적 보완이 필요하다는 견해가 지배 적이다 [29-31].

특히 본 연구에서 주목하고 있는 CM247LC 초내열합금 은 용접 응고균열에 취약한 소재로, 가스터빈 블레이드 제 조 시 응고균열 저감형 용가재 적용이 검토되고 있다. 실 제 용접 시공에 앞서 용가재 성분과 희석률 등의 세부 용 접 조건에 따른 응고균열 민감도 평가는 필수적이라고 할 수 있지만, 이에 대한 국내 연구는 상당히 부족한 실정이 다. 본 연구에서는 이종 용접부에 적용 가능한 수정된 방 식의 Varestraint 시험 절차를 고안하였고, 이를 통해 용가 재 적용에 따른 CM247LC 초내열합금 용접부 응고균열
민감도 변화거동을 정량 평가하였다. 용가재로는 상용 $\mathrm{ERNiFeCr}-2$ 합금을 사용하였고, 민감도 평가 결과 및 고 안한 시험법의 타당성은 그림 1 에서 설명한 응고균열 현 상의 야금학적 이론에 기반하여 고찰하였다. 최종적으로 도 출된 결과들은 $\mathrm{CM} 247 \mathrm{LC}$ 초내열합금 가스터빈 블레이드 의 고건전성 용접부 제조에 활용하고자 한다.

\section{2. 사용재료 및 실험방법}

\section{1 사용재료}

표 1은 $\mathrm{CM} 247 \mathrm{LC}$ 합금(모재) 및 $\mathrm{ERNiFeCr}-2$ 용가재(직 경: $1.6 \mathrm{~mm}$ )의 화학성분을 나타낸다. CM247LC 합금은 Cannon Muskegon 사의 상용 모합금을 이용해 판재 형상

(a)
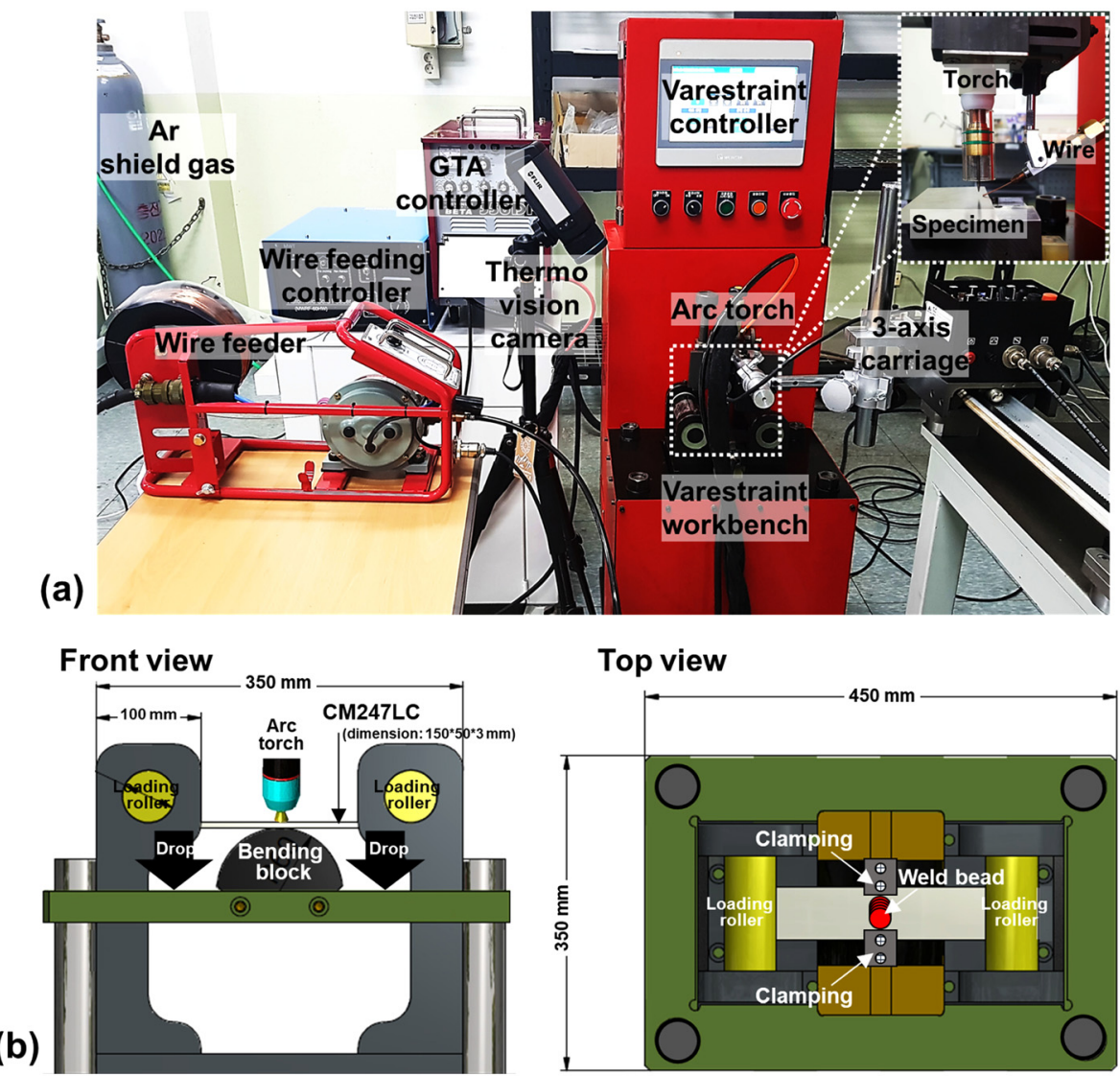

Fig. 2. (a) appearance and (b) schematic illustration of the transverse-Varestraint test with GTAW. 


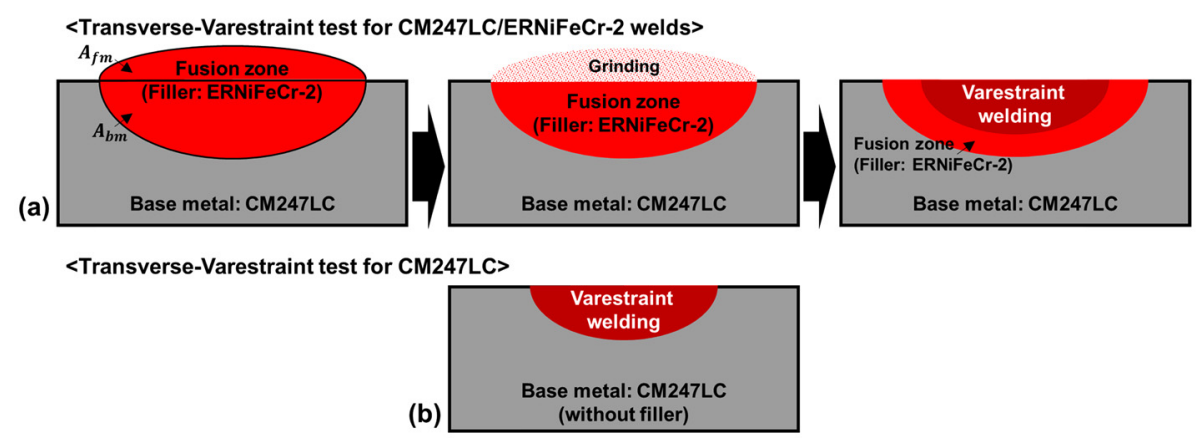

Fig. 3. Schematic descriptions of transverse-Varestraint test for (a) CM247LC/ERNiFeCr-2 welds and (b) typical transverse-Varestraint test.

$(150 \times 50 \times 3 \mathrm{~mm})$ 으로 주조 제작한 뒤 용체화 열처리 $(1505 \mathrm{~K}-120$ 분)를 적용하였다.

\section{2 실험방법}

$\mathrm{CM} 247 \mathrm{LC}$ 초내열합금 및 $\mathrm{ERNiFeCr}-2$ 용가재를 적용한 $\mathrm{CM} 247 \mathrm{LC}$ 용접부(CM247LC/ERNiFeCr-2) 응고균열 민감 도를 정량 평가하기 위해 transverse-Varestraint 시험을 실 시하였다. 그림 2는 (a)고속 열화상 카메라와 와이어 송급 장치를 포함한 가스텅스텐 아크용접(Gas Tungsten Arc Welding, GTAW) 기반의 Varestraint 시험 장비 및 (b)시 험과정 모식도를 나타낸다. 그림 3(a)는 본 연구에서 고안 한 이종 용접부 Varestraint 시험과정을 설명하고 있다. $\mathrm{CM} 247 \mathrm{LC}$ 에 $\mathrm{ERNiFeCr}-2$ 용가재를 적용한 단층(singlepass) $\mathrm{GTAW}$ (아크 전류: $100 \mathrm{~A}$, 아크 전압: $18 \mathrm{~V}$, 용접 속도: $1 \mathrm{~mm} / \mathrm{s}$ ) 뒤, 해당 용접 비드 내에서 제살 용접과 함께 transverse-Varestraint 시험을 실시하였다. Varestraint 시험 시의 굽힘 변형률 신뢰도를 고려하여 용가재 적용에 따른 비드표면 덧살(face reinforcement)은 평활하게 연마 처리 후 Varestraint 시험을 실시하였다. CM247LC/ $\mathrm{ERNiFeCr}-2$ 용접부에 대한 평가 결과는 CM247LC 합금 transverse-Varestraint 시험 결과와 함께 비교 검토하였다(그 림 3(b)). Transverse-Varestraint 시험에서 굽힘 변형은 제살 용접 종료와 동시에 부가하였고, 시험 주요 조건은 표 2에 요약하였다. Varestraint 시험 시 응고균열 형성 시점의 온 도분포는 고속 열화상카메라(A655sc, FLIR)로 가시화 측 정하였으며(그림 2(a)), 해당 결과를 통해 응고균열 발생온 도범위(Solidification Brittle Temperature Range, BTR)를 도출하였다. 온도 가시화를 위한 고속 열화상카메라 사양 은 표 3에 요약하고 있으며, 온도 측정 결과의 정밀도 향 상을 위해 방사율(emissivity)은 0.6 으로 설정하였다. Varestraint 시험부의 응고균열 길이 측정에는 실체현미경
Table 2. Conditions of the transverse-Varestraint test with GTAW.

\begin{tabular}{cc}
\hline Parameters & Conditions \\
\hline Welding & Direct current GTAW \\
Arc voltage $(\mathrm{V})$ & 10 \\
Arc current $(\mathrm{A})$ & 60 \\
Arc length $(\mathrm{mm})$ & 2 \\
Welding speed $(\mathrm{mm} / \mathrm{s})$ & 1 \\
Shield gas & Argon $(99.99 \%$ purity $)$ \\
Bending strain $(\%)$ & $0.5-3.0$ \\
Bending rate $(\mathrm{mm} / \mathrm{s})$ & 400 \\
\hline
\end{tabular}

Table 3. Specifications of the infrared-thermovision camera.

\begin{tabular}{cc}
\hline Parameters & Conditions \\
\hline Frame rate $(\mathrm{fps})$ & 50 \\
Temperature acquisition range $(\mathrm{K})$ & $298-2273$ \\
Temperature acquisition accuracy $(\mathrm{K})$ & $\pm 2 \mathrm{~K}$ \\
Temperature resolution $(\mathrm{mK})$ & $<30$ \\
Time response $(\mathrm{ms})$ & $<8$ \\
Emissivity & 0.6 \\
\hline
\end{tabular}

(ISM-PM200SB, Insize)을 사용하였다.

\section{3 미세조직 분석}

Varestraint 시험부의 응고균열 발생 양상은 주사전자현미 경 (scanning electron microscopy, SEM)으로 관찰하였다. 응고균열부의 미세 성분 분포는 전자탐침미세분석기 (Electron Probe Micro Analyze, EPMA, JXA-8530F, $\mathrm{JEOL})$ 를 이용해 분석하였다.

\section{3. 실험결과 및 고찰}

\subsection{CM247LC 및 CM247LC/ERNiFeCr-2 용접부 응고균열 거동}




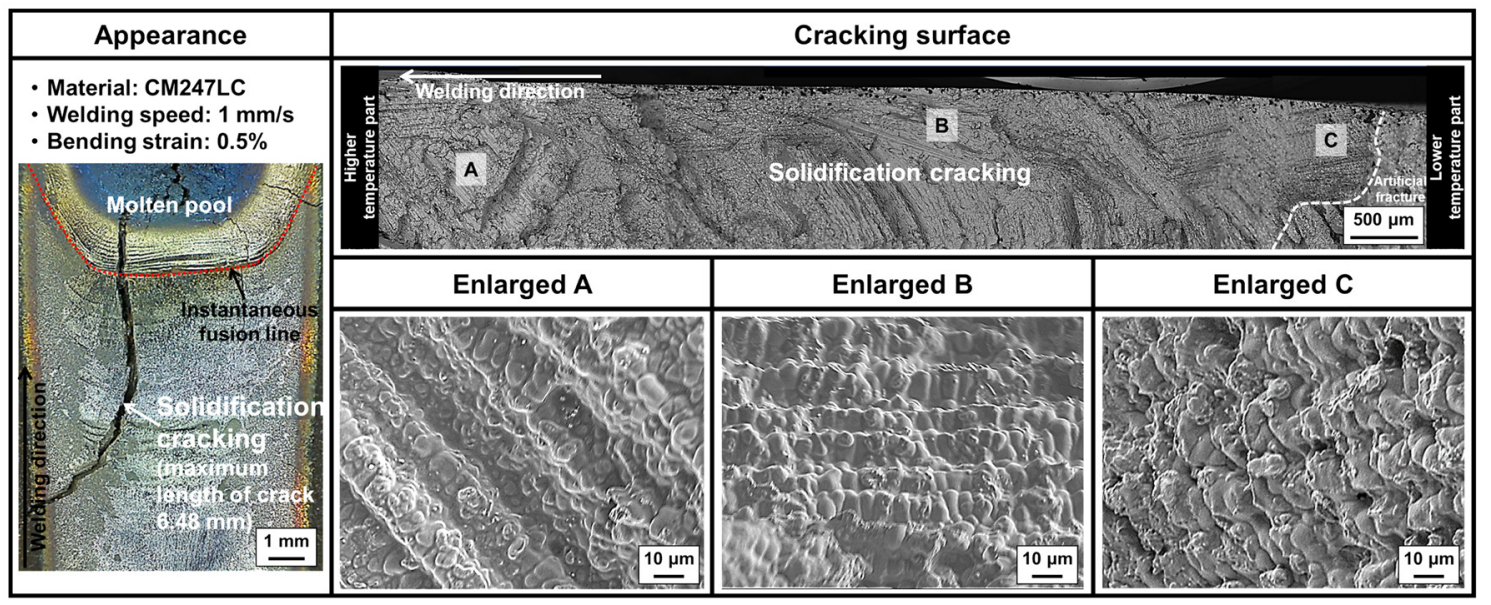

Fig. 4. Appearance and microstructural characteristics (SEM) of solidification cracking surface after the transverse-Varestraint test for CM247LC specimen.

그림 4는 CM247LC 합금의 transverse-Varestraint 시험 (부가 변형률: $0.5 \%$ ) 대표 결과를 나타낸다. 시험부 외관에 서 고온균열 형성을 확인할 수 있으며(최대 균열길이: $6.48 \mathrm{~mm})$, 균열 파면 $(\mathrm{SEM}$ 사진) 전 영역에서 덴드라이트 형상 및 액막이 관여한 흔적이 명확히 관찰되는 바, 해당 고온균열은 응고균열로 판별되었다. 파면의 고온부는 연속 적 액막 분리에 기인하는 'Type $\mathrm{D}$ ' (dendritic fracture) 특성을 나타내고, 저온부는 ‘Type D'와 불연속적 액막 분 리에 기인하는 'Type F' (flat fracture) 특성이 혼재하는 결과를 보인다. 그림 5 는 $\mathrm{CM} 247 \mathrm{LC} / \mathrm{ERNiFeCr}-2$ 용접부 에 대한 transverse-Varestraint 시험 결과를 나타낸다(부가 변형률: $1.0 \%$ ). CM247LC 시험 결과(그림 4)와 마찬가지 로, 비드 중앙부에서 고온균열 형성을 확인할 수 있으며(최 대 균열길이: $4.58 \mathrm{~mm}$ ), 파면 형상은 고온부 'Type $\mathrm{D}$ ', 저온부 'Type $\mathrm{F}$ ' 특성을 나타내는 응고균열로 판별되었다. 따라서 CM247LC 및 $\mathrm{CM} 247 \mathrm{LC} / \mathrm{ERNiFeCr}-2$ 용접부 모 두 Varestraint 시험에서 확인된 균열은 응고균열로 확인되 었으며, 각 응고균열 파면 형상의 상이함은 $\mathrm{ERNiFeCr}-2$ 용가재 희석에 의한 액막 거동의 차이에 기인하는 것으로 추정된다.

\subsection{ERNiFeCr-2 용가재 적용에 따른 CM247LC 합금 응고균열 민감도 변화}

본 절에서는 그림 4 및 5 에서 확인된 각 용접부의 응고 균열 발생거동을 BTR로 정량화 하였다. 그림 6 은 고속 열화상카메라로 측정한 Varestraint 시험 용접응고 시의 온 도구배를 나타낸다. 열화상 카메라로부터 도출한 온도구배 신뢰성 검증을 위해, Varestraint 시험 굽힘변형 부가 시점

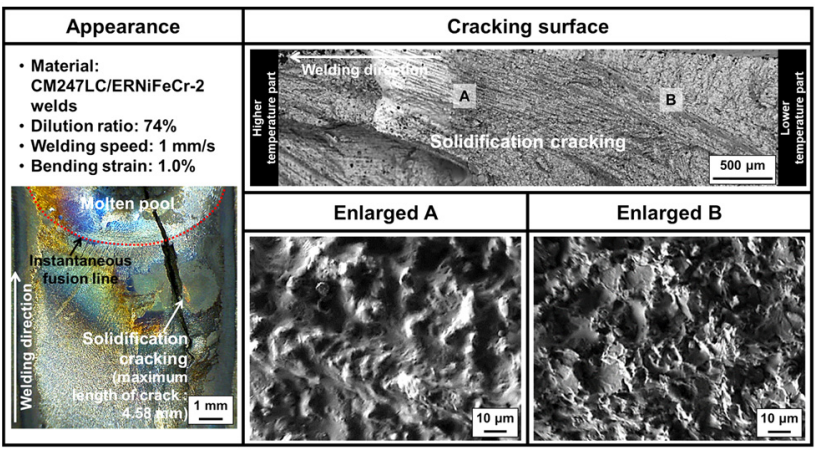

Fig. 5. Appearance and microstructural characteristics (SEM) of solidification cracking surface after the transverse-Varestraint test for $\mathrm{CM} 247 \mathrm{LC} / \mathrm{ERNiFeCr}-2$ welds.

의 일시적 용융지 경계선(그림 4,5 의 instantaneous fusion line) 상의 온도가 각 소재의 평형 액상선 온도 (Thermo-Calc 계산)임을 확인하였다(CM247LC: $1669 \mathrm{~K}$, $\mathrm{CM} 247 \mathrm{LC} / \mathrm{ERNiFeCr}-2$ 용접부: $1653 \mathrm{~K}) . \mathrm{CM} 247 \mathrm{LC} /$ $\mathrm{ERNiFeCr}-2$ 용접부의 액상선 온도는 희석률과 혼합법칙 (rule of mixture)에 기반하여 계산했으며, 자세한 과정은 3.3절에서 설명하고자 한다. Varestraint 시험에서 형성된 최대 응고균열 길이를 고려하여 온도구배는 용융지 경계선 으로부터 $5 \mathrm{~mm}$ 범위에서 도출하였다. 그 결과 CM247LC 합금 Varestraint 시험 시의 온도구배는 $61.66 \mathrm{~K} / \mathrm{mm}$, $\mathrm{CM} 247 \mathrm{LC} / \mathrm{ERNiFeCr}-2$ 용접부의 온도구배는 $106.08 \mathrm{~K} /$ $\mathrm{mm}$ 로 얻어졌다.

각 온도구배를 이용하여 응고균열 발생에 대한 고온연성 곡선(high temperature ductility curve) 및 BTR을 도출하 였고, 그림 7은 해당 결과를 나타낸다. 굽힘 변형률 $0.5 \%$ 


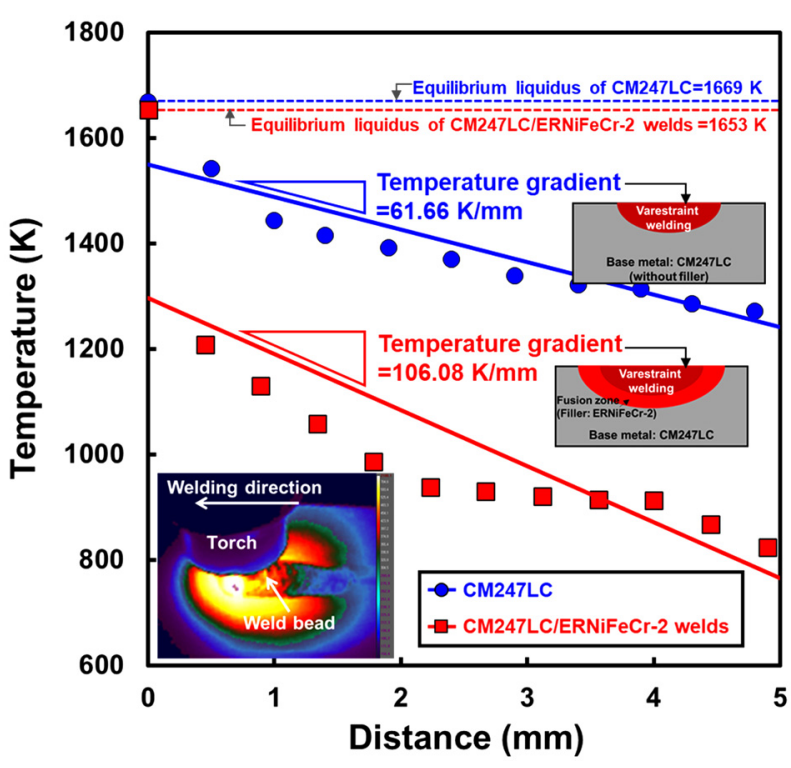

Fig. 6. Temperature gradient in transverse-Varestraint test measured by thermo-vision camera for CM247LC and CM247LC/ERNiFeCr2 welds.

에서 균열발생 온도범위는 포화 및 유지되는 결과를 보이 고, $\mathrm{CM} 247 \mathrm{LC}$ 합금의 $\mathrm{BTR}$ 은 $400 \mathrm{~K}, \mathrm{CM} 247 \mathrm{LC} /$ $\mathrm{ERNiFeCr}-2$ 용접부 $\mathrm{BTR}$ 은 $486 \mathrm{~K}$ 로 각각 평가되었다. $400 \mathrm{~K}$ 이라는 BTR은 비교적 응고균열에 취약하다고 알려 진 고용강화형 초내열합금 Inconel 625(BTR: $205 \mathrm{~K}$ ) 대비 약 $200 \%$ 큰 값인 것을 알 수 있고 [32], 이는 CM247LC 합금의 가스터빈 블레이드 적용 시, 용접 응고균열 민감도 억제를 위한 소재 및 공정 조건 최적화가 반드시 선행되어 야 함을 시사한다. 특히 $\mathrm{ERNiFeCr-2}$ 적용은 $\mathrm{CM} 247 \mathrm{LC}$ 합금 $\mathrm{BTR}$ 을 $86 \mathrm{~K}$ 확대시키는 결과를 확인할 수 있으며, 용가재 적용 시에는 성분에 따른 BTR 변화거동을 면밀하 게 검토할 필요가 있음을 확인할 수 있는 부분이다. $\mathrm{Ni}$ 계 초내열합금 용접 응고균열 민감도 평가에 대한 다양한 선 행연구 결과가 보고되고 있지만 [32], CM247LC 초내열합 금 및 상용 용가재 적용에 따른 응고균열 민감도 변화에 대한 결과는 상당히 부족한 실정이었다. 따라서 본 연구에 서 고안한 $\mathrm{BTR}$ 평가 절차 및 $\mathrm{ERNiFeCr-2}$ 적용에 따른 $\mathrm{CM} 247 \mathrm{LC}$ 용접부 응고균열 민감도 변화거동은 향후 가스 터빈 블레이드 적용 및 고건전성 용접부 제조에 있어 유효 한 시험과정 및 야금학적 지표가 될 것으로 판단된다.

\subsection{ERNiFeCr-2 용가재 적용에 따른 Laves 상} 형성 및 고액공존 온도범위 변화

용접 응고균열은 고상 및 액상 공존영역에서 형성되는

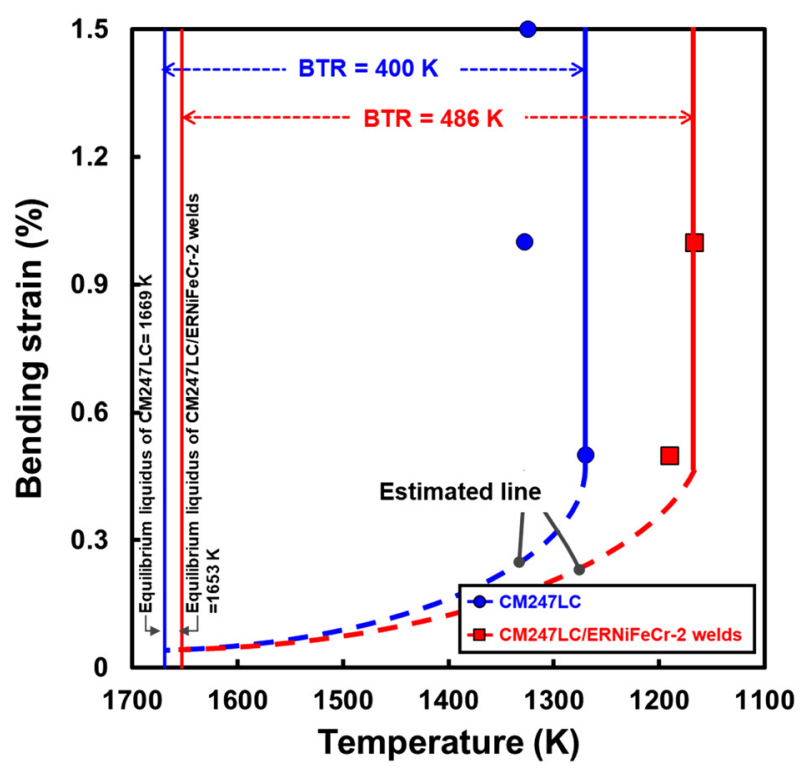

Fig. 7. High temperature ductility curve and BTR for solidification cracking of CM247LC and CM247LC/ERNiFeCr-2 welds.

균열로, $\mathrm{Ni}$ 계 초내열합금의 경우 $\mathrm{BTR}$ 과 고액공존 온도범 위는 비례관계를 가지는 것으로 잘 알려져 있다 [32]. 따라 서 본 절에서는 3.2 절에서 평가한 $\mathrm{CM} 247 \mathrm{LC}$ 및 $\mathrm{CM} 247 \mathrm{LC} / \mathrm{ERNiFeCr}-2$ 용접부 $\mathrm{BTR}$ 거동에 대해, 각각의 고액공존 온도범위 및 응고거동 계산 결과를 기반으로 이론 고찰하였다.

고액공존 온도범위의 도출을 위해 $\mathrm{CM} 247 \mathrm{LC} / \mathrm{ERNiFeCr}-$ 2 용접금속(fusion zone) 조성은, 식 (1)의 혼합법칙(rule of mixture)과 희석률 계산식을 이용하였다 [32]. $C_{f z}^{i}$ 는 용접 금속 내 합금원소 $i$ 의 성분, $C_{b m}^{i}$ 는 모재 상의 $i$ 성분, $C_{f m}^{i}$ 는 용가재 상의 $i$ 성분, $D$ 는 용접부의 희석률 $(=74 \%)$ 이다. 희석률 $(D)$ 계산 과정은 식(2)에 나타내고 있으며, $A_{b m}, A_{f m}$ 은 각각 모재부 용접금속과 덧살의 단면적으로 그 림 2(a)에 표시하였다. 표 4는 $\mathrm{CM} 247 \mathrm{LC} / \mathrm{ERNiFeCr}-2$ 용 접부 성분 계산 결과를 나타낸다.

$$
\begin{aligned}
& C_{f z}^{i}=D C_{b m}^{i}+(1-D) C_{f m}^{i} \\
& D=\frac{A_{b m}}{A_{b m}+A_{f m}} \times 100
\end{aligned}
$$

그림 8 은 $\mathrm{CM} 247 \mathrm{LC}, \mathrm{ERNiFeCr}-2$ 및 $\mathrm{CM} 247 \mathrm{LC} /$ $\mathrm{ERNiFeCr}-2$ 용접부 고액공존 온도범위를 Thermo$\mathrm{Calc}(\mathrm{TCNi})$ 로 계산한 결과이다. 계산 결과는 평형상태도 상의 고액공존 온도범위와 Scheil 식( $99 \%$ 응고완료)으로 
Table 4. Calculated chemical composition of CM247LC/ERNiFeCr-2 weld fusion zone.

\begin{tabular}{cccccccccccccccc}
\hline $\mathrm{Ni}$ & $\mathrm{C}$ & $\mathrm{Cr}$ & $\mathrm{Fe}$ & $\mathrm{Co}$ & $\mathrm{Mo}$ & $\mathrm{Mn}$ & $\mathrm{W}$ & $\mathrm{Ta}$ & $\mathrm{Nb}$ & $\mathrm{Ti}$ & $\mathrm{Al}$ & $\mathrm{B}$ & $\mathrm{Zr}$ & $\mathrm{Hf}$ & $\mathrm{Si}$ \\
\hline Bal. & 0.065 & 10.35 & 4.82 & 6.99 & 1.1 & 0.01 & 7.2 & 2.49 & 1.16 & 0.77 & 4.37 & 0.011 & 0.011 & 1.06 & 0.022 \\
\hline
\end{tabular}

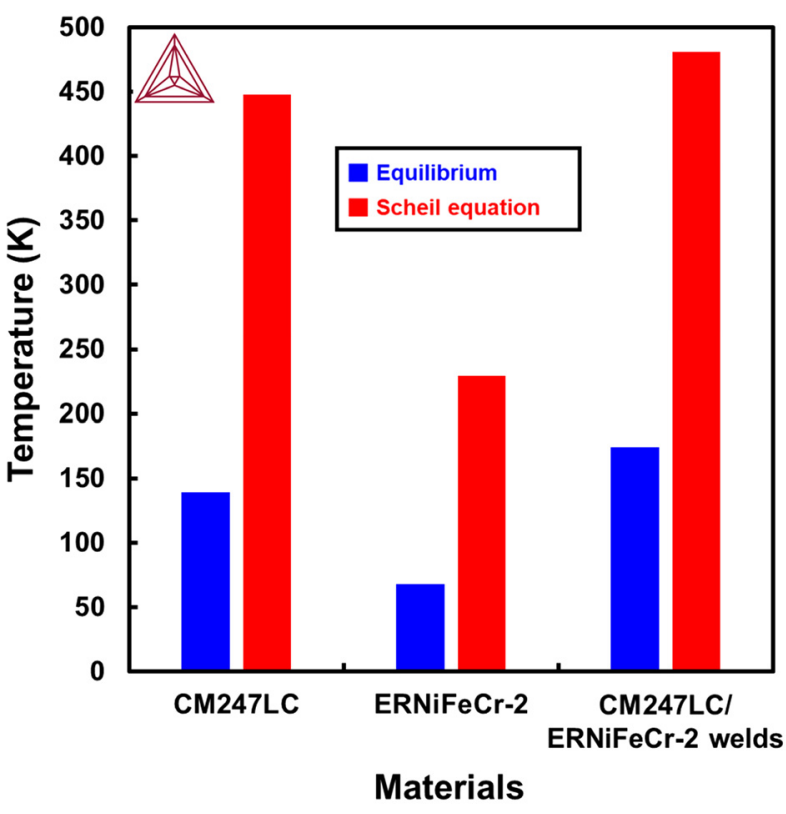

Fig. 8. Calculated mushy zone range by equilibrium condition and Scheil equation for CM247LC, ERNiFeCr-2 and CM247LC/ ERNiFeCr-2 welds.

계산한 비평형 고액공존 온도범위 2종으로 정리하였다. 평 형상태 고액공존 온도범위 및 Scheil 식 결과값 모두 $\mathrm{CM} 247 \mathrm{LC}$ (평형상태: $139 \mathrm{~K}, \mathrm{Scheil}: 448 \mathrm{~K}$ ) 대비 $\mathrm{CM} 247 \mathrm{LC} / \mathrm{ERNiFeCr}-2$ 용접부(평형상태: $174 \mathrm{~K}$, Scheil: $481 \mathrm{~K}$ )가 넓은 결과를 확인할 수 있다. 따라서 $\mathrm{ERNiFeCr-2}$ 용가재 적용에 따른 BTR 확대 거동(그림 7)은 $\mathrm{ERNiFeCr-2}$ 성분 희석에 따른 고액공존 온도범위 확대에 기인하는 것으 로 사료된다.

한편 그림 8 에 나타낸 바와 같이 $\mathrm{ERNiFeCr}-2$ 용가재의 평형상태 및 Scheil 계산 고액공존 온도범위는 각각 $68 \mathrm{~K}$, $229 \mathrm{~K}$ 으로, CM247LC 합금 고액공존 온도범위 대비 약 $50 \%$ 수준인 것을 확인할 수 있다. 그럼에도 불구하고 $\mathrm{CM} 247 \mathrm{LC} / \mathrm{ERNiFeCr}-2$ 용접부의 고액공존 온도범위는 확 대되는 현상을 확인할 수 있으며, 이는 Scheil 식 계산 결 과에서 응고 최종단계(응고 진행률 $90 \%$ 이상)의 저융점 상 형성 및 응고균열 파면 상의 미세조직 거동을 통해 설 명 가능하였다. 그림 9는 (a) CM247LC, (b) ERNiFeCr-2 그리고 (c) $\mathrm{CM} 247 \mathrm{LC} / \mathrm{ERNiFeCr}-2$ 용접부에 대한 Scheil 식 응고과정(solidification path) 계산 결과이다. CM247LC 합금은 응고 진행률 약 $96 \%$ 부터 $\mathrm{MC}$ 탄화물이 형성되며,
약 $1200 \mathrm{~K}$ 까지 잔류액상(residual liquid)이 존재하지만, $\mathrm{CM} 247 \mathrm{LC} / \mathrm{ERNiFeCr}-2$ 용접부는(그림 9(c)), 약 97\% 응 고 진행률부터 형성되는 Laves 상과 함께 약 $1173 \mathrm{~K}$ 까지 잔류액상이 존재하고, 그 결과 CM247LC 합금 대비 고액 공존 온도범위가 확대되는 세부 결과를 확인할 수 있다. 그 림 9(b)의 $\mathrm{ERNiFeCr}-2$ 용가재 계산 결과를 볼 때, $\mathrm{CM} 247 \mathrm{LC} / \mathrm{ERNiFeCr}-2$ 용접부 Laves 상 형성은 $\mathrm{ERNiFeCr}-$ 2 성분의 영향으로 추정된다.

보편적으로 Laves 상 $\left((\mathrm{Ni}, \mathrm{Cr}, \mathrm{Fe})_{2}(\mathrm{Nb}, \mathrm{Mo}, \mathrm{Ti})\right)$ 은 $\mathrm{Nb}$ 첨가 형 초내열합금 용접 응고과정에서 형성되는 대표적인 TCP(topologically close packed)상으로, 응고 최종 단계에 서 $\gamma /$ Laves 공정조직을 형성시켜 고액공존 온도범위 및 $\mathrm{BTR}$ 를 확대시키는 것으로 알려져 있다 [32-34]. 그림 10 은 그림 $9(\mathrm{c})$ 의 $\mathrm{CM} 247 \mathrm{LC} / \mathrm{ERNiFeCr}-2$ 용접부 Scheil식 계산 과정에서 얻을 수 있는, (a)응고 진행률에 따른 Laves 상분율 변화, (b)응고 진행률에 따른 기지상 (gamma, $\gamma$ )의 $\mathrm{Nb}$ 성분 변화 결과를 나타낸다. 약 $97 \%$ 응고 진행률에서 Laves 상 형성을 명확히 확인할 수 있으 며(그림 10(a)), 이는 $\gamma$ 내의 급격한 $\mathrm{Nb}$ 성분 감소 시점 과 일치한다(그림 $10(\mathrm{~b}))$. 따라서 $\mathrm{CM} 247 \mathrm{LC} / \mathrm{ERNiFeCr}-2$ 용접부의 고액공존 온도범위 확대에 핵심적인 영향을 미치 는 Laves 상 형성은 $\mathrm{ERNiFeCr}-2$ 용가재 상의 $\mathrm{Nb}$ 성분 희석에 기인하는 것으로 판단된다.

그림 11은 $\mathrm{CM} 247 \mathrm{LC} / \mathrm{ERNiFeCr}-2$ 용접부 응고균열 파 면(그림 5)에서, “A”(고온부) 및 “B” 영역(저온부)에 대한 EPMA 분석결과이다. $\mathrm{Nb}, \mathrm{Cr}, \mathrm{Mo}, \mathrm{Ti}$ 등의 성분 분포 결과를 토대로 응고균열 파면 전 영역에서 Laves 상의 형 성을 확인할 수 있다. 따라서 그림 9,10에서 설명한 $\mathrm{CM} 247 \mathrm{LC} / \mathrm{ERNiFeCr}-2$ 용접부 고액공존 온도범위 확대에 미치는 $\mathrm{Nb}$ 희석 및 Laves 상 형성의 영향(그림 $9(\mathrm{c}))$ 은 실제 응고균열 거동 및 $\mathrm{BTR}$ 확대에 적용될 수 있는 이론 적 기구로 판단된다. 특히 표 4에 나타낸 바와 같이, $\mathrm{CM} 247 \mathrm{LC} / \mathrm{ERNiFeCr}-2$ 용접부에는 약 $4.82 \%$ 의 $\mathrm{Fe}$ 이 존 재하는 것으로 계산되고, $\mathrm{Fe}$ 는 $\mathrm{Nb}$ 응고편석을 심화시켜 $\left(\mathrm{Nb}\right.$ 분배계수 $\left(\mathrm{k}_{\mathrm{Nb}}\right)$ 감소 야기) Laves 상과 같은 $\mathrm{TCP}$ 상 형성을 촉진시키는 현상 또한 보고되고 있다 [35]. 따라서 고액공존 온도범위가 협소한 $\mathrm{ERNiFeCr-2}$ 용가재 적용에도 불구하고, $\mathrm{CM} 247 \mathrm{LC} / \mathrm{ERNiFeCr}-2$ 용접부의 $\mathrm{BTR}$ 이 확대 되는 것은, 기본적으로 $460 \mathrm{~K}$ 라는 $\mathrm{CM} 247 \mathrm{LC}$ 합금의 넓 


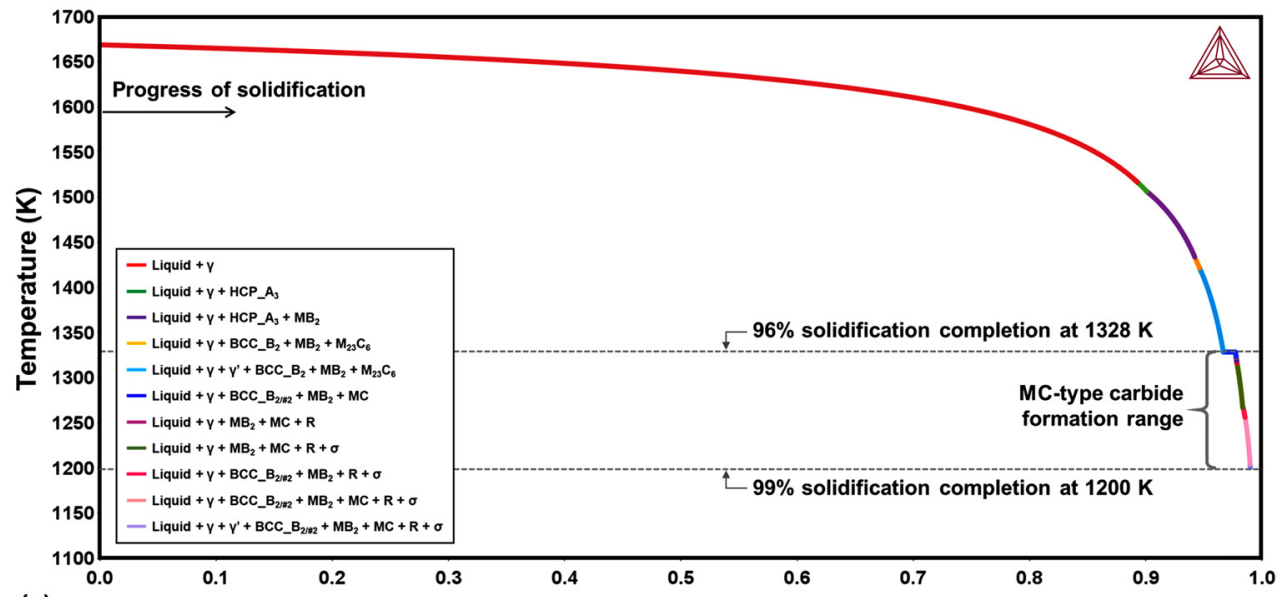

(a)

Mole fraction of solid

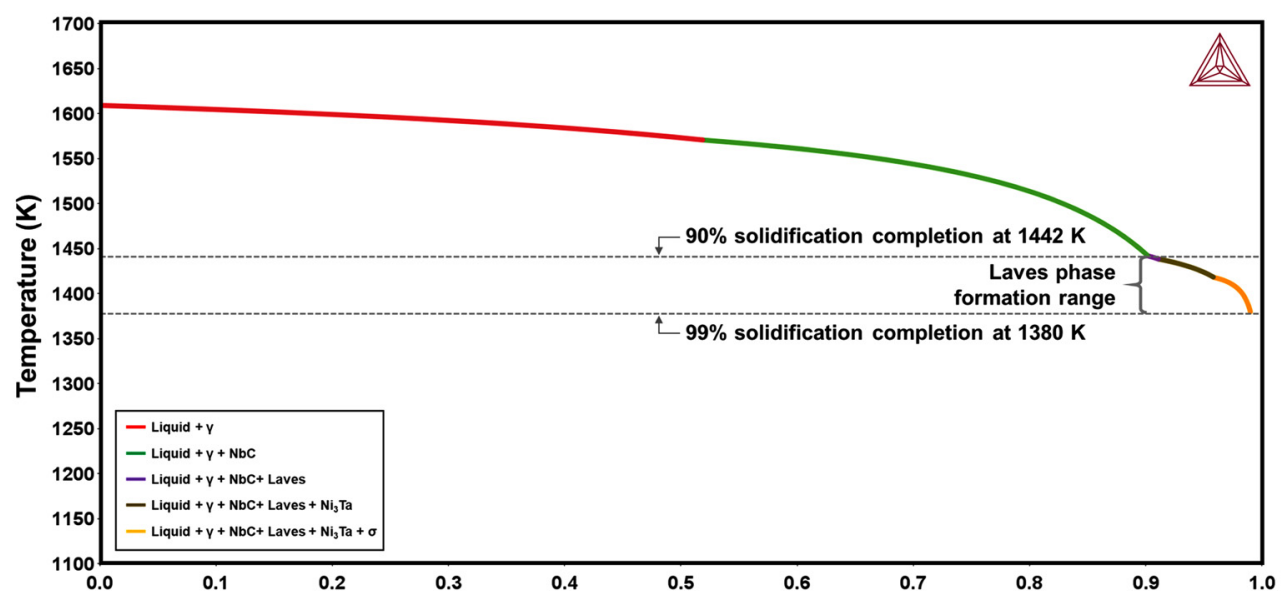

(b)

Mole fraction of solid

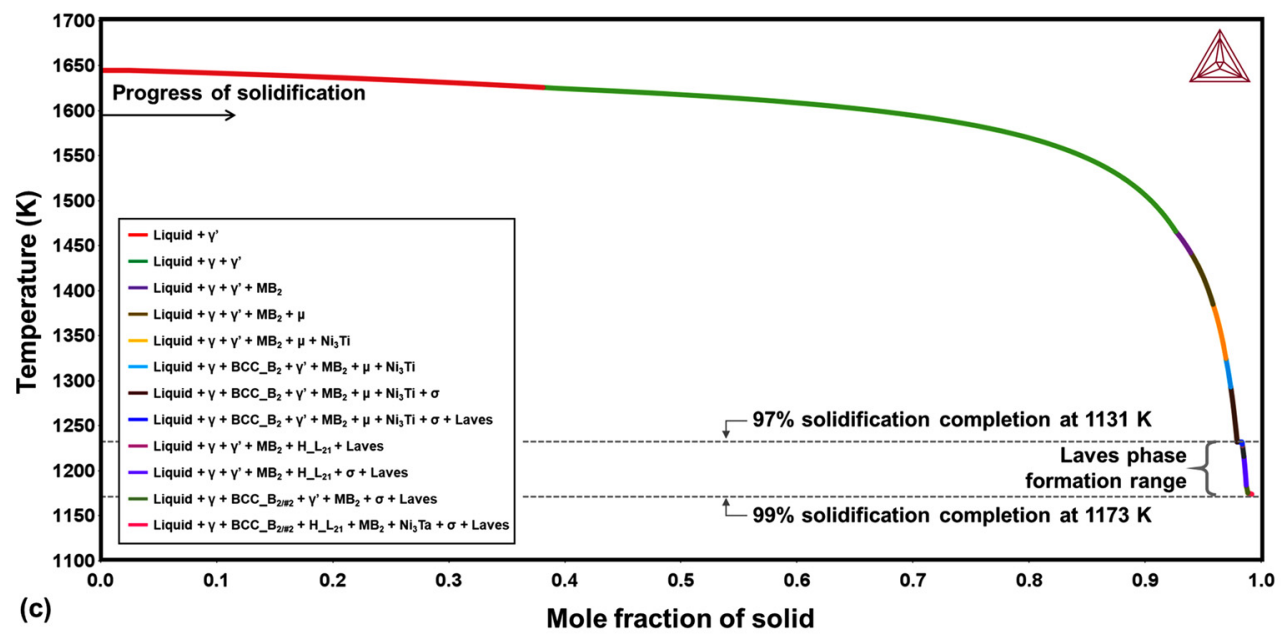

Fig. 9. Solidification path for (a) CM247LC, (b) ERNiFeCr-2 and (c) CM247LC/ERNiFeCr-2 welds calculated by Thermo-Calc.

은 고액공존 온도범위에 $\mathrm{ERNiFeCr}-2$ 용가재 상의 $\mathrm{Nb}$ 및 $\mathrm{Fe}$ 희석에 의한 Laves 상 형성과 그에 따른 고액공존 온 도범위 추가 확대가 반영된 결과로 사료된다.

\section{4. 결 론}

본 연구에서는 새롭게 고안한 Varestraint 시험 절차를 

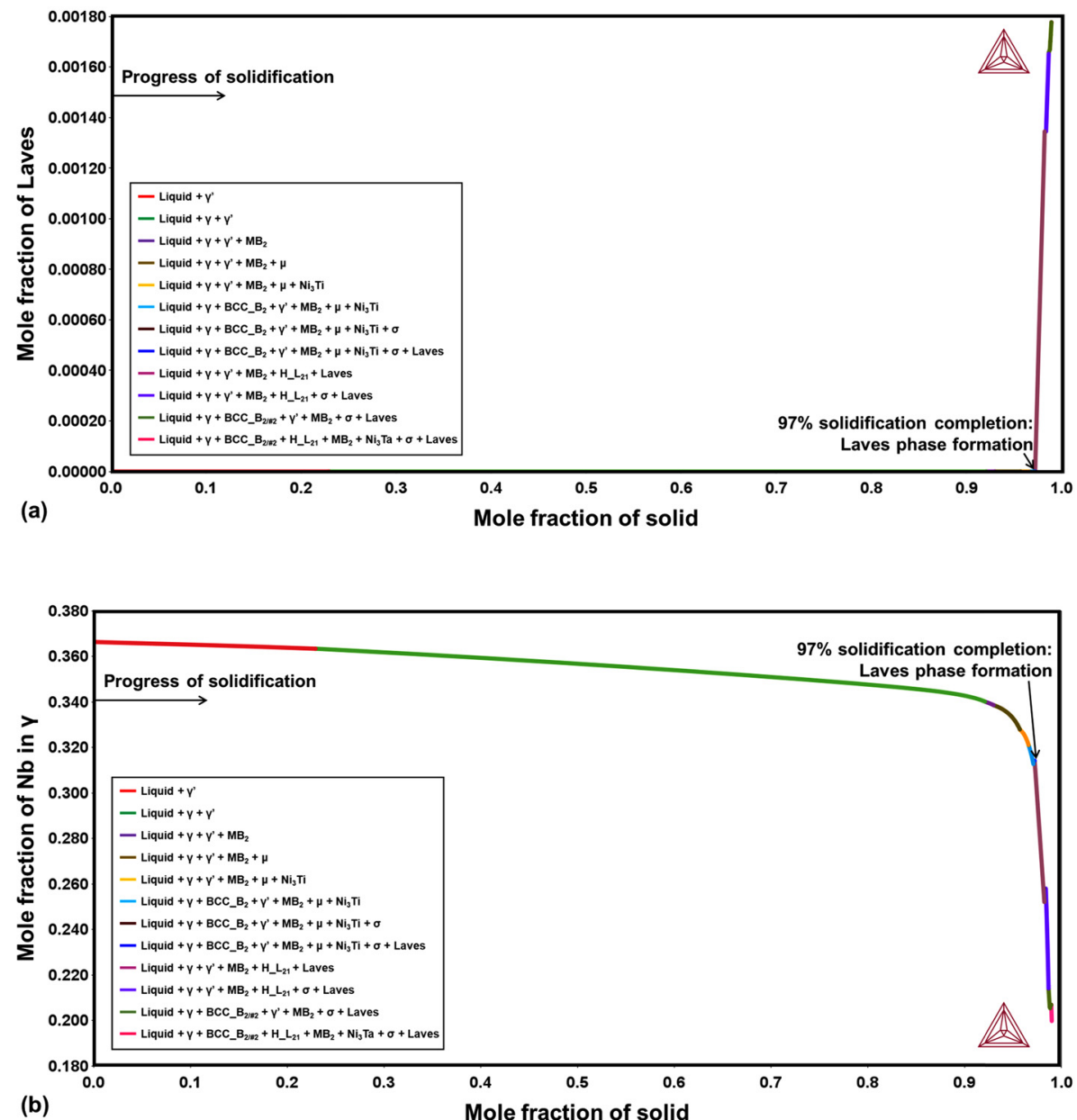

Fig. 10. Relationship between (a) Laves phase formation and (b) $\mathrm{Nb}$ segregation behavior in $\gamma$ during the solidification $\mathrm{CM} 247 \mathrm{LC} /$ ERNiFeCr-2 welds calculated by Thermo-Calc.

이용해 CM247LC 초내열합금 가스터빈 블레이드 용접 제 조 시, $\mathrm{ERNiFeCr}-2$ 용가재 적용에 따른 응고균열 민감도 변화를 정량 평가하였으며, 평가 결과는 균열 파면 상의 미세조직 분포와 열역학적 응고계산을 연계하여 이론 고찰 하였다. 아래와 같이 본 연구의 결론을 요약한다.

1. 단층 $\mathrm{GTAW}$ 를 통해 $\mathrm{CM} 247 \mathrm{LC} / \mathrm{ERNiFeCr}-2$ 용접부 를 제조하였고(희석률 $74 \%$ ), Varestraint 시험 및 시험과정 의 온도가시화를 통해 응고균열 민감도, 즉 $\mathrm{BTR}$ 을 평가할 수 있었다. 그 결과 $\mathrm{CM} 247 \mathrm{LC}$ 합금 $\mathrm{BTR}$ 은 $400 \mathrm{~K}$, $\mathrm{CM} 247 \mathrm{LC} / \mathrm{ERNiFeCr}-2$ 용접부 $\mathrm{BTR}$ 은 $486 \mathrm{~K}$ 로 평가되었 다. 즉 $\mathrm{ERNiFeCr}-2$ 용가재 적용을 통해 $\mathrm{CM} 247 \mathrm{LC}$ 대비 $86 \mathrm{~K}$ 의 $\mathrm{BTR}$ 확대가 확인되며, 본 결과는 용가재 적용으로 인한 용접부 성분변화 및 그에 따른 BTR 거동을 면밀하 게 검토할 필요가 있음을 시사한다.

2. $\mathrm{ERNiFeCr}-2$ 용가재 적용에 따른 $\mathrm{CM} 247 \mathrm{LC}$ 합금 $\mathrm{BTR}$ 확대 거동은, $\mathrm{EPMA}$ 를 통한 응고균열 파면 미세조직
분석 및 Scheil 식 응고계산을 통한 고액공존 온도범위 변 화 거동을 통해 고찰 가능하였다. 그 결과, $\mathrm{BTR}$ 확대는 $460 \mathrm{~K}$ 라는 $\mathrm{CM} 247 \mathrm{LC}$ 합금의 넓은 고액공존 온도범위에, $\mathrm{ERNiFeCr}-2$ 성분 $(\mathrm{Nb})$ 희석에 의한 저융점 Laves 상 형성 및 그에 따른 고액공존 온도범위 추가 확대(481 K)가 반영 된 결과로 판단되었다.

3. 응고균열 파면 상의 미세조직 분포와 Scheil 식 응고 계산을 통해 본 연구에서 고안한 이종 용접부 $\mathrm{BTR}$ 평가 절차 및 해당 결과의 신뢰성을 확인할 수 있었으며, 이는 향후 $\mathrm{CM} 247 \mathrm{LC}$ 합금의 가스터빈 블레이드 적용 및 고건 전성 용접부 제조에 있어 유효한 응고균열 민감도 평가 방 법으로 활용될 것으로 판단된다.

\section{감사의 글}

본 연구는 산업통상자원부의 재원으로 한국산업기술평가 
(a)

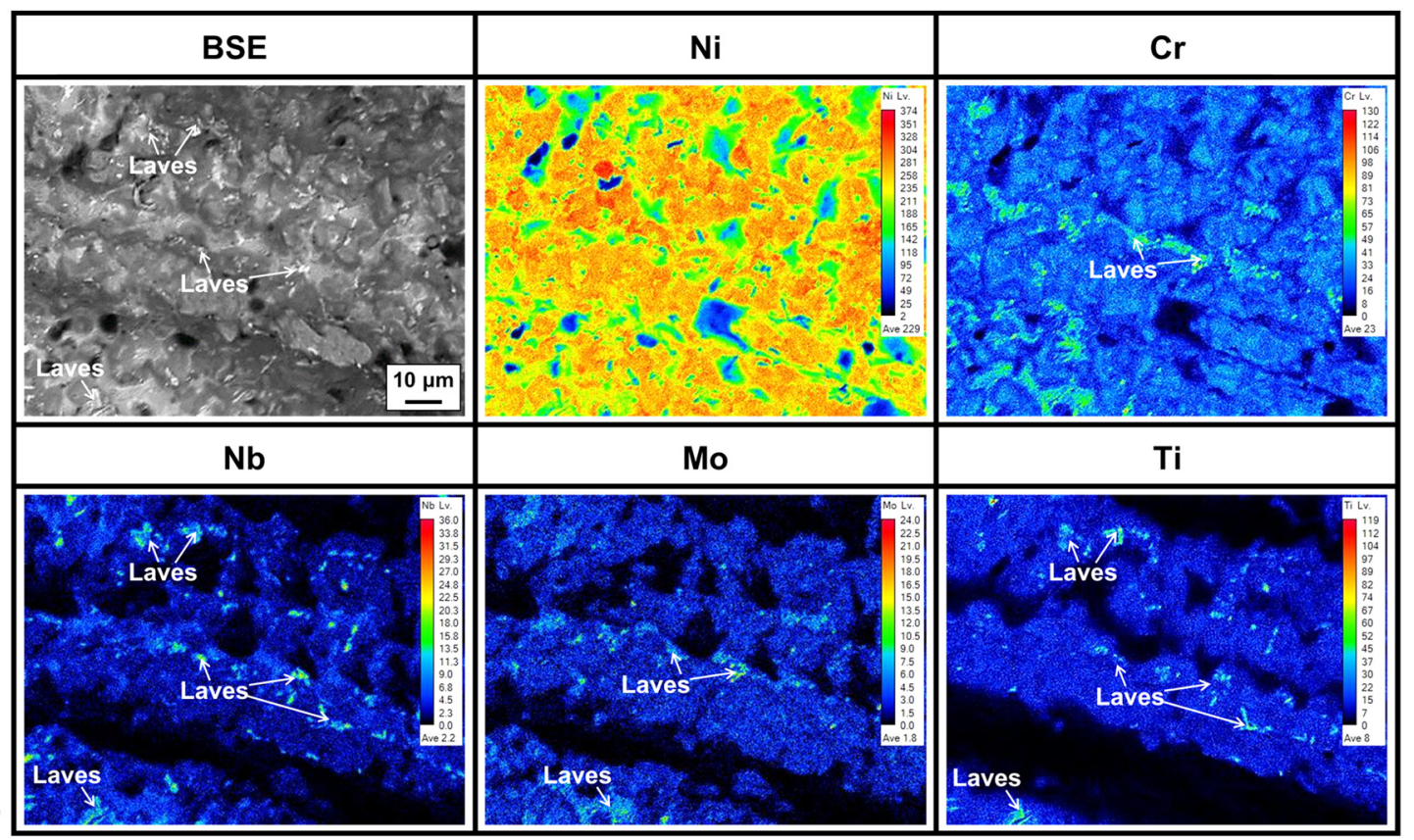

(b)

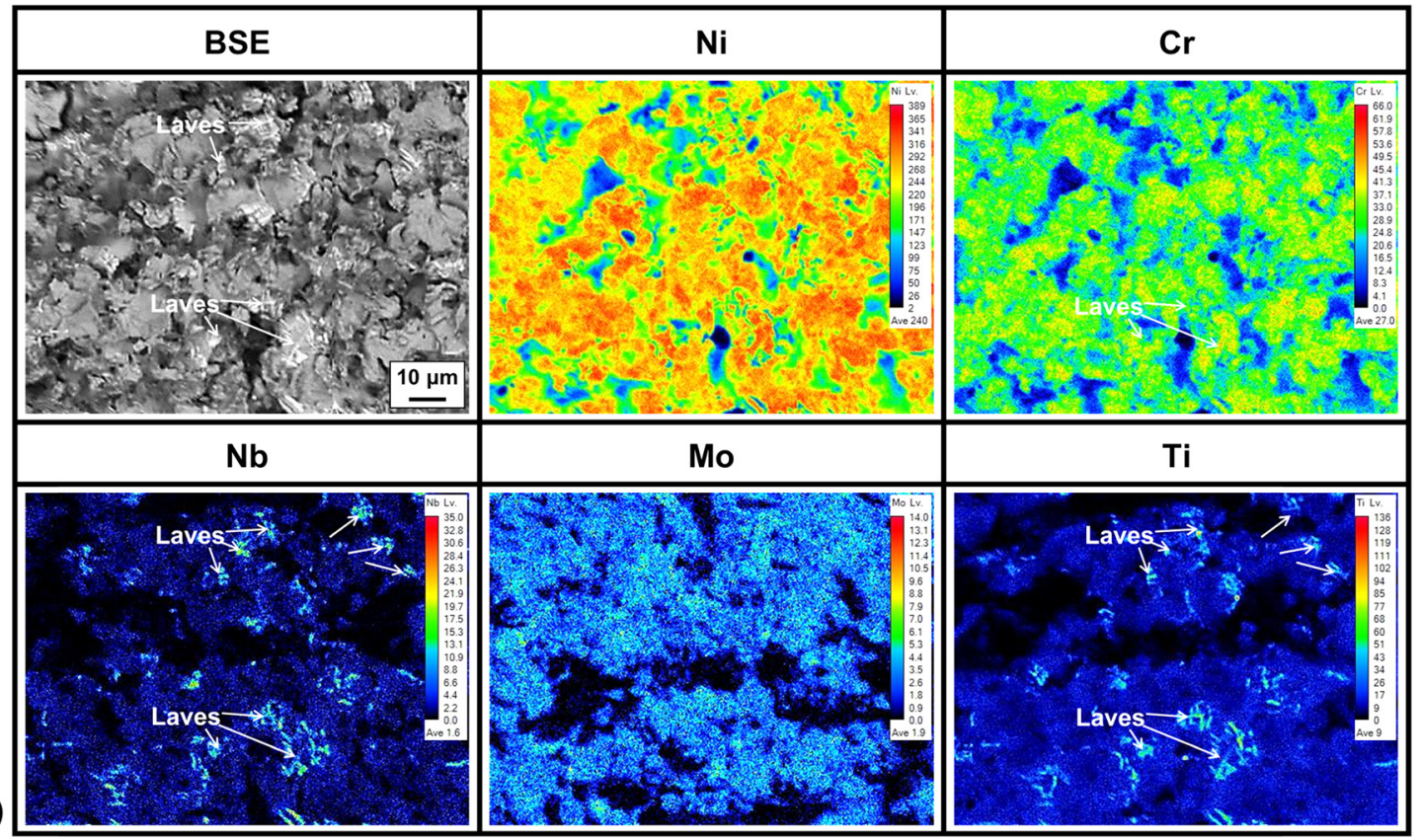

Fig. 11. Back-scattered electron (BSE) image and element distribution at the solidification cracking surface of CM247LC/ERNiFeCr-2 welds for (a) "A" and (b) "B" region designated in Fig. 5.

관리원 (전략핵심소재자립화기술개발사업, No. 20011103) 및 한국에너지기술평가원 (에너지인력양성사업, No. 20214000000480)의 지원을 받아 수행되었음. 과학기술정 보통신부의 재원으로 한국연구재단 (개인연구지원사업, No. 2019R1G1A1099607)의 지원을 받아 수행되었음.

\section{REFERENCES}

1. I. S. Kim, B. G. Choi, S. M. Seo, D. H. Kim, and C. Y. Jo, Mater. Lett. 62, 1110 (2008).

2. S. M. Seo, H. W. Jeong, D. W. Yun, Y. K. Ahn, J. H. Lee, and Y. S. Yoo, J. Korea Foundry Soc. 33, 193 (2013).

3. Y. S. Jeong, K. M. Kim, U. Lee, H. Lee, S. M. Seo, and E. 
J. Chun, Korean J. Met. Mater. 58, 875 (2020).

4. N. Kalentics, N. Sohrabi, H. G. Tabasi, S. Griffiths, J. Jhabvala, C. Leinenbach, A. Burn, and R. E. Loge, Addit. Manuf. 30, 100881 (2019).

5. K. T. Hsu, H. S. Wang, H.G. Chen, and P. C. Chen, Metals 6, 238 (2016).

6. J. C. Lippold, Welding Metallurgy and Weldability, pp 84 129, John Wiley \& Sons, Inc., New Jersey (2015).

7. S. Kou, Acta Mater. 88, 366 (2015).

8. T. Kannengiesser, and T. Boellinghaus, Weld. World 58, 397 (2014).

9. B. I. Medovar, Automatic Welding 7, 12 (1954).

10. W. R. Apblett, and W. S. Pellini, Weld. J. 33, 83s (1954).

11. J. C. Borland. Brit. Weld. J. 7, 508 (1960).

12. F. Matsuda, H. Nakagawa, and K. Sorada. Trans. JWRI 11, 67 (1982)

13. F. Matsuda, H. Nakagawa, S. Tomita, and K. Sorada, Quart. J. Jpn Weld. Soc, 6, 82 (1988).

14. N. N. Prokhorov, and N. N. Prokhorov, Transaction of the Japan Welding Society 2, 109 (1971).

15. U. Feurer, Proceedings International Symposium on Engineering Alloys, 131, Delft, Netherlands (1977).

16. W. Kurz, B. Giovanola, and R. Trivedi, Acta Metall. Mater. 34, 823 (1986).

17. K. Nishimoto, K. Saida, K. Kiuchi, and J. Nakayama, Hot Cracking Phenomena in Welds III (J. C. Lippold, T. Bollinghaus, C. E. Cross eds.), 183, Springer, Berlin (2011).

18. E. J. Chun, H. Baba, K. Nishimoto, and K. Saida, Cracking Phenomena in Welds IV (J. C. Lippold, T. Bollinghaus, C. E. Cross eds.), 161, Springer, Switzerland (2015).

19. M. Rappaz, J. M. Drezet, and M. Gremaud, Metall. Mater. Trans. A, 30A, 449 (1999).

20. W. Rindler, E. Kozeschnik, N. Enzinger, and B. Buchmayr, Mathematical Modeling of Weld Phenomena VI (H. H.
Cerjak, H. K. D. H. Bhadeshia eds.), 819, CRC Press, London (2002).

21. S. Yamashita and K. Saida, Quart. J. Jpn Weld. Soc. 38, 275 (2020).

22. G. M. Goodwin, Weld. J. 66, 33 (1987)

23. K. Shinozaki, H. Kuroki, X. Luo, H. Ariyoshi, and M. Shirai, Weld. Int. 13, 952 (1999).

24. F. C. Hull, Weld. J. 38, 176s (1959).

25. B. T. Alexandrov and J. C. Lippold, Weld. World 57, 635 (2013).

26. A. Kromm and T. Kannengiesser, Hot Cracking Phenomena in Welds II (T. Bollinghaus, H. Herold, C. E. Cross, J. C. Lippold eds.), 77, Springer, Berlin (2008).

27. H. Herold, A. Pshennikov, and M. Streitenberger, Hot Cracking Phenomena in Welds (T. Bollinghaus, H. Herold eds.), 328, Springer, Berlin, (2005).

28. W. F. Savage and C. D. Lundin, The Varestraint test. Weld. J. 44, 433 (1965).

29. K. Kadoi, S. Okano, S. Yamashita, D. Abe, A. Takemori, S. Yamada, A. Takada, and J. Kawata, Quart. J. Jpn Weld. Soc. 37, 200 (2019).

30. D. Abe, F. Matsuzaka, Y. Murakami, T. Matsuoka, and H. Yamaoka, Weld. World 62, 1237 (2018).

31. E. J. Chun, H. Baba, K. Nishimoto, and K. Saida, Met. Mater. Int. 21, 543 (2015).

32. J. N. Dupont, J. C. Lippold, and S. D. Kiser, Welding Metallurgy and Weldability of Nickel-Base Alloys, 157, John Wiley \& Sons, New Jersey (2009).

33. Y. Kim, B. Moon, N. Kang, and E. J. Chun, Korean J. Met. Mater. 58, 403 (2020).

34. M. J. Sohrabi and H. Mirzadeh, Met. Mater. Int. 26, 326 (2020).

35. J. N. DuPont, C. V. Robino, and A. R. Marder, Acta Mater. 46, 4781 (1998). 